\title{
GLACIOLOGICAL AND CHEMICAL CHARACTERISTICS \\ OF AN ANTARCTIC INLAND PLATEAU \\ (Abstract)
}

\author{
by
}

Y. Ageta

(Water Research Institute, Nagoya University, Furo-cho, Chikusa-ku, Nagoya 464, Japan)

K. Kamiyama,

(Geophysical Research Station, Kyoto University, Noguchihara, Beppu 874, Japan)

F. Okuhira

(Gifu Prefectural Research Institute for Environmental Pollution, 58-2, Yabuta 8-chome, Gifu 500, Japan)

and

Y. Fujii and $\mathrm{O}$. Watanabe

(National Institute of Polar Research, 9-10, Kaga 1-chome, Itabashi-ku, Tokyo 173, Japan)

\section{ABSTRACT}

A glaciological research project in east Queen Maud Land, Antarctica, has been carried out by the Japanese Antarctic Research Expeditions between 1982 and 1986 (JARE-23 - JARE-27).

In this paper, we deal with the area traversed by JARE-25 and JARE-26, a representative inland plateau in Antarctica. In 1984, a team from JARE-25 extended a route from Mizuho Station (MS) to an advanced camp ( $A C$; $74^{\circ} 12^{\prime} \mathrm{S}, 34^{\circ} 59^{\prime} \mathrm{E}$; $3200 \mathrm{~m}$ a.s.1.) and returned to $\mathrm{MS}$ via the Yamato Mountains region. In the following year, 1985, a team from JARE-26 reached the summit $\left(77^{\circ} 22^{\prime} \mathrm{S}, 39^{\circ} 37^{\prime} \mathrm{E}\right.$; $3810 \mathrm{~m}$ a.s.l.) of an ice dome on the plateau behind $\mathrm{AC}$ and continued to Asuka camp, north of Sør-Rondane Mountains. Investigations were carried out along the routes as follows:

Geomorphological observations: the altitude along the routes was measured, together with the depth of the bedrock, which was obtained by radio echo-sounding. The shape of the dome and the position of ice divides were revealed. Gravity soundings were also carried out along the routes.

Depositional and erosional environments of the snow surface: the net accumulation rate was obtained along the routes by the stake method. Sastrugi orientations were recorded in order to gain information on the prevailing wind. At several points, vertical profiles of snow stratigraphy and snow hardness were obtained, together with snow temperatures at $10 \mathrm{~m}$ depth. The glaciological characteristics of the plateau are described with reference to these results.

Snow chemistry: the values of the electro-conductivity and $\mathrm{pH}$ of melted snow along the routes were obtained, and the results show high conductivity and low $\mathrm{pH}$ values around the dome region. Quantitative studies on the chemical composition of the samples are continuing.

Ice coring: at the dome camp (DC; $77^{\circ} 00^{\prime} \mathrm{S}, 35^{\circ} 00^{\prime} \mathrm{E}$; $3760 \mathrm{~m}$ a.s.1.), coring was carried out to a depth of $40 \mathrm{~m}$. In the samples, we have been studying the vertical distribution of $\delta^{18} \mathrm{O}$ and the products of nuclear fission, in order to determine the accumulation rate and the atmospheric environment.

On the basis of the results described above, the relationship between meteorological and glaciological conditions in the inland plateau are discussed. 